\title{
Drawing a Link-Women's Empowerment and Mahatma Gandhi National Rural Employment Guarantee Act: A Study Conducted in the Goalpara District, Assam
}

\author{
Dr Manisha Bhattacharyya ${ }^{+}$
}

\begin{abstract}
This article reports on an empirical research that examined the extent of economic empowerment gained by women engaged in Mahatma Gandhi National Rural Employment Guarantee Act (MGNREGA) in the district of Goalpara, Assam. The key objective of the MGNREGA is to provide social security to rural households by guaranteeing 100 days of paid employment in public works within a year. Based on nine variables (education, land ownership, ownership of other assets, control over income contributed by a woman to her family, control over the income of the family, savings, access to credit, social participation, cash income earned from income generating activities) and calculated using empowerment index, the research compared the magnitude of women's empowerment before and after getting involved in MGNREGA. The findings suggest that while MGNREGA is an important leap to ensuring economic empowerment to rural women, but the scheme has not been implemented properly in the district-women and men not getting 100 days of employment, irregular mode of payment, very slow progress and poor quality in public works.
\end{abstract}

Key words: Women's empowerment, empowerment index, MGNREGA, Goalpara district, Assam, India

\footnotetext{
${ }^{\dagger}$ Assistant Professor, Department of Economics, Goalpara College, Goalpara, Assam. Email: mikubhatta@gmail.com (C) 2016 Bhattacharyya. This is an Open Access article distributed under the terms of the Creative Commons Attribution License (http://creativecommons.org/licenses/by/2.0), which permits unrestricted use, distribution, and reproduction in any medium, provided the original work is properly cited.
} 


\section{Introduction}

There is a large literature on issues linked to rural women's empowerment through the largest public works scheme of India-The National Employment Guarantee Act, 2005, first started in 200 districts since 2 February 2006 and renamed after the Father of the Nation as Mahatma Gandhi National Rural Employment Act (MGNREGA) since 02 October 2009 on his 140th birth anniversary (Dutta et al., 2012; Fraser, 2015; Liu and Barret, 2013; Narayanan and Das, 2014; also Bhattacharyya and Vauquline, 2013; Bhattacharyya et al., 2011). Underscoring the human rights notion of 'right to work', the Act guarantees 100 days of paid employment in unskilled works to poor rural households within a financial year aimed at granting social security (Dutta et al., 2012). Apart from this basic objective, the other objectives of the act are-the creation of durable assets and strengthening the livelihood resources based on the rural poor, generation of productive assets, protection of environment, empowerment of rural women, reduction of rural-urban migration and fostering social equity. However, after a decade of performance, evidence suggests that MGNREGA has been suffering from massive funding cuts apace with corruption and issues associated with poor implementation (Fraser, 2015; Ghosh, 2015).

While the overall success and failure of this scheme has been widely researched upon in different states as well as India as a whole (Bhattacharyya and Vauquline, 2013; Bhattacharyya et al., 2011; Dutta et al., 2012; Fraser, 2015; Liu and Barret, 2013; Sudarshan, 2011), this research aims to examine the scale of economic empowerment gained by women engaged in Mahatma Gandhi National Rural Employment Guarantee Act (MGNREGA) in the district of Goalpara, Assam.

The article begins with an attempt to draw a connection between women's empowerment and MGNREGA. It then goes on to discuss the methodological issues concerning this research followed by the results and discussion section.

\footnotetext{
${ }^{1}$ Fourth World Conference on Women, Beijing Declaration, and Retrieved from
}

\section{Constructing the Connection between Women's Empowerment and MGNREGA}

Women's empowerment always had an economic dimension to it. However, this has become more visible in international policy discourse after the Beijing Platform for Action which spoke of the need to promote women's economic independence, including employment, and "ensuring equal access for all women...to productive resources, opportunities and public services." ${ }^{1}$ Economic empowerment is the capacity of women and men to participate in, contribute to and benefit from growth processes in ways which recognize the value of their contributions, respect their dignity and make it possible to negotiate a fairer distribution of the benefits of growth (Eyben, et al., 2008; Sarma, 2009). Thus, when we talk about women's economic empowerment, it means women's access to economic resources and opportunities including jobs, financial services, property and other productive assets, skills development and market information (Bhattacharyya, 2009; 2013; Sarma, 2009).

The Millennium Development Goals on gender equality and women's empowerment adopted an increase in women's share of non-agricultural employment as one of its indicators of women's empowerment. Although these documents did not define women's economic empowerment, their formulation shifted the focus on women's economic empowerment and their access to productive resources, including paid work. The World Bank was one of the first agencies to explicitly define women's economic empowerment: 'Economic empowerment is about making markets work for women (at the policy level) and empowering women to compete in markets (at the agency level)' (World Bank, 2006). Following this, women's economic empowerment has been defined by different agencies and individual studies with slight modifications. In an ICRW (International Centre for Research on Women) publication by Golla et al. (2011), a woman is considered economically empowered when she has the ability to succeed and advance economically and the power to

http://www.un.org/womenwatch/daw/beijing/platform/ declar.htm (accessed 01 December 2015). 
make and act on economic decisions. Similarly, Tornqvist and Schmitz (2009: 9), on women's economic empowerment defined it as "the process which increases women's real power over economic decisions that influence their lives and priorities in society. Women's economic empowerment can be achieved through equal access to and control over critical economic resources and opportunities, and the elimination of structural gender inequalities in the labour market including a better sharing of unpaid care work."

As stated above, MGNREGA is an important milestone for prompting economic empowerment to the rural women (Bhattacharyya et al., 2011; Bhattacharyya and Vauquline, 2013; Fraser, 2015). The National Rural Employment Guarantee Act, 2005 was passed unanimously in the Lok Sabha (Lower House of the Parliament) on 23 August 2005 (Dutta et al., 2012; Fraser, 2015; Liu and Barret, 2013; Sudarshan, 2011). After the successful implementation of Maharashtra Employment Guarantee Act, since 1976 in Maharashtra, this scheme started since 2 February, 2006 across all over India, first launched at P. Bandlapalli (a tiny village of Narpala Mandal) in Ananthapur district of Andhra Pradesh on 16 February 2006. Prior to this wage employment scheme, the Government of India had launched a number of wage employment schemes, National Rural Employment Programme (NREP, 1980), Rural Landless Employment Guarantee Programme (RLEGP, 1983), Jawahar Rozgar Yojana (JRY, 1989) Employment Assurance Scheme (EAS, 1993), Jawahar Gramin Samradh Yojana (JGSY, 1999) and Swarnajayanti Gramin Rozgar Yojana (SGRY, 2001).

Following are the type of works that are included in MGNREGA

- Water conservation and water harvesting

- Drought proofing (including afforestation and tree plantation)

- Irrigation canals including micro and minor irrigation works

- Provision of irrigation facility to land owned by households belonging to the SC and ST or to land of beneficiaries of land reforms or that of the beneficiaries under the Indira Awas Yojana of the Government of India

- Renovation of traditional water bodies including desilting of tanks

- Land development

- Flood control and protection works including drainage in water logged areas

- Rural connectivity to provide all weather access

- Any other works which may be notified by the Central Government in consultation with the State Government. It is widely believed that MGNREGA helps rural women in two ways: first, by providing as a continuous source of income generation and second, by upgrading the social status of rural women - a path to economic independence and hence, empowerment of women. Using Jo Rowland's arguments on the notion of power [that is, "power over (ability to influence and coerce); power with (power from collective action); power within (self-reliance and selfconfidence) and power to (organise and change existing hierarchies)"], Bhattacharyya and Vauquline (2013: 86) have shown as to how MGNREGA has served as a 'rural life line' to the women employees of Assam, whereby, MGNREGA has helped women to a great extent to "develop their consciousness" and [enabled them to take] own decisions (power within) to bring about transformation in their own family" (Bhattacharyya and Vauquline, 2013: 92; Bhattacharyya, et al., 2011; Fraser, 2015; Sudarshan, 2011). Taking into account these backgrounds, this research is an attempt to examine women's empowerment at MGNREGA in the district of Goalpara, Assam. The next section discusses the methodological issues.

\section{Methodological Issues}

This research, as mentioned above, was carried out in Ambari village, under Ranjuli block in the district of Goalpara where MGNREGA was implemented in the first phase. Goalpara is one of the most backward districts of the country as recognised by the Ministry of Panchayat Raj and thereby the recipient of Backward Regions Grant 
Fund Programme. ${ }^{2}$ The study village is $7 \mathrm{~km}$ away from the National Highway-31. Dhkuwar hill and river Deosila are located in the two sides of the village and other two sides are covered by agricultural fields. The village is a home to 7540 people (3840 males and 3700 females); out of which 6450 are literates (3041 female literates and 3409 male literates). Total working population is 3000 and the sex ratio is 925female per 1000-male. Among 124 Scheduled Caste (SC) populations 65 are females and 59 are males. Similarly, among the 130 Scheduled Tribe (ST) populations, 56 are females and 74 are males. Total unemployed persons in the village before the implementation of the scheme were 2000 and after the implementation are 1400.

The research is based on both primary and secondary data. Secondary data has been collected from the block and Panchayat office. In addition, focus groups were conducted to understand the perception, opinion and awareness about the scheme. Primary data has been collected from the beneficiaries either as a part of the survey conducted individually or as a part of focus groups. For this, a household survey schedule was conducted to collect information among these beneficiaries. Prior to conducting this research however, consents were taken from the participants regarding their participation.

Since the start of this scheme in the village, a total of 595 persons (including males and females) became job card holders. For this research, I conducted $10 \%$ of the total job card holders selected randomly, which is a total of 60 beneficiaries - to understand the impact of the scheme in terms of the socio-economic status of the households after the implementation of MGNREGA. The collected data were analysed using simple statistical analysis like calculation of percentage, average have been worked out and presented in tabular format, while empowerment index has been calculated to determine the degree of empowerment of women's employment under MGNREGA in the Ambari village.

\footnotetext{
2 Ministry of Panchayati Raj (2009, 8 September). A Note on the Backward Regions Grant Fund Programme, National Institute of Rural Development
}

\section{Results and Discussion}

As discussed above, the first step of the research was to probe about the awareness about MGNREGA among the inhabitants of Ambari village. While it is apparent from Table 1, that 100 percent are aware about the programme of MGNREGA, 86.67 percent of the respondents are aware about the job card. However, majority (76.66\%) of the respondents are ignorant about the process of submission of the form to get involved under MGNREGA.

Again only 33.33 percent of the respondents know about the payment on wage at minimum wage rate and 20 percent know about social audit system whereas not a single person knows about Right to Information (RTI). It is also observed that nobody raised the problem on retrieving a job card, involvement of middle man, discrepancies in social audit and oblivious about RTI.

Table 2 illustrates the variables and their categorisation and scoring which determines the scale of women's empowerment. This Table presents that the variables-land ownership, ownership of other assets, control over own income, control over income of the family are found to remain constant but the variables like education, income, saving, social participation, credit creation are different before and after implementation of the MGNREGA.

The scores obtained from these nine variables (that is, education, land ownership, ownership of other assets, control over income contributed by her to the family, control over the income of the family, savings, access to credit, social participation, cash income earned from income generating activities), the degree of women's empowerment has been calculated by computing the empowerment index and expressed in percentage as follows: 


\section{Table 1: Awareness about Mahatma Gandhi National Rural Employment Guarantee Act}

\begin{tabular}{|c|c|c|c|c|}
\hline Variables & Yes & $\%$ & No & $\%$ \\
\hline 1. Awareness about MGNREGA & 60 & 100 & 0 & 0 \\
\hline 2. Awareness about job cards & 52 & 86.66 & 8 & 13.33 \\
\hline 3. Awareness about submission of application to get work under MGNREGA card & 14 & 23.33 & 46 & 76.66 \\
\hline 4. Awareness about the payment on wage at minimum wage rate & 20 & 33.33 & 40 & 66.66 \\
\hline 5. Awareness about the social audit & 12 & 20 & 48 & 80 \\
\hline 6. Awareness about Right to Information (RTI) & 0 & 0 & 60 & 100 \\
\hline
\end{tabular}

Source: Author

\section{Table 2: Determinants of Empowerment and their Scores}

\begin{tabular}{|c|c|c|c|c|}
\hline \multirow[t]{2}{*}{ Independent Variables } & \multirow[t]{2}{*}{ Category } & \multirow[t]{2}{*}{ Score } & \multicolumn{2}{|c|}{$\begin{array}{c}\text { Observed Frequencies } \\
(\mathrm{N}=60)\end{array}$} \\
\hline & & & Before & After \\
\hline \multirow[t]{5}{*}{ Education } & Illiterate & 0 & 30 & 5 \\
\hline & Primary School & 1 & 20 & 41 \\
\hline & Middle School & 2 & 10 & 12 \\
\hline & High School & 3 & 0 & 2 \\
\hline & College Education & 4 & 0 & 0 \\
\hline \multirow[t]{3}{*}{ Land Ownership } & No Land & 0 & 55 & - \\
\hline & Joint Ownership & 1 & 2 & - \\
\hline & Independent Ownership & 2 & 3 & - \\
\hline \multirow[t]{3}{*}{ Ownership of Other Assets } & No Assets & 0 & 50 & - \\
\hline & Joint Ownership & 1 & 10 & - \\
\hline & Sole Ownership of Other Assets & 2 & 0 & - \\
\hline \multirow[t]{3}{*}{ Control over own income } & No Control & 0 & 45 & - \\
\hline & Partial Control & 1 & 10 & - \\
\hline & Full Control & 2 & 5 & - \\
\hline \multirow[t]{3}{*}{ Control over Income of Family } & No Control & 0 & 60 & - \\
\hline & Partial Control & 1 & 0 & - \\
\hline & Full Control & 2 & 0 & - \\
\hline \multirow[t]{3}{*}{ Savings } & No Savings & 0 & 55 & 40 \\
\hline & Up to $25 \%$ of Earnings & 1 & 2 & 20 \\
\hline & up to $50 \%$ of Earnings & 2 & 0 & 0 \\
\hline \multirow[t]{3}{*}{ Access to Credit } & No Access & 0 & 0 & 50 \\
\hline & Joint Access & 1 & 0 & 10 \\
\hline & Access to Credit & 2 & 0 & 0 \\
\hline \multirow[t]{3}{*}{ Social Participation } & Not a Member in any Organisation & 0 & 0 & 5 \\
\hline & Member in one Organisation & 1 & 5 & 50 \\
\hline & Member in more than one Organisation & 2 & 0 & 5 \\
\hline \multirow[t]{3}{*}{ Cash Income earned from Income Generating Activities (₹/month) } & $₹ 0-5000 /-$ & 1 & 59 & 10 \\
\hline & ₹ 5001/- -10,000/- & 2 & 1 & 40 \\
\hline & $₹>10,000 /-$ & 3 & 0 & 10 \\
\hline
\end{tabular}




$$
\text { Empowerment Index }=\frac{\text { Score Obtained }}{\text { Maximum Score Obtainable }} \times 100
$$

Empowerment Index (before involvement in MGNREGS) $=\frac{86}{540} x 100=15.93$

Empowerment Index (after involvement in MGNREGS) $=\frac{259}{540} x 100=47.96$

Thus, gain in empowerment is 32.03

These calculations signal that involvement in income generating activities in MGNREGA contributed for enhancement in the scale of women's empowerment. Clearly, these analyses indicate that involvement of women in MGNREGA led to empowerment of rural women in the realms of education, savings, and access to credit, social participation and cash income earned through income generating activities. These findings bear resonance to a number of previous studies (Bhattacharyya et al., 2011; Bhattacharyya and Vauquline, 2013; Fraser, 2015; Sudarshan, 2011).

\section{Concluding Remarks}

It remains well documented that economic empowerment is the backbone to women's empowerment that ensures provision of training, employment- and income-generation activities with both forward and backward linkages with the ultimate objective of making all women economically independent and selfreliant (Bhattacharyya et al., 2011; Bhattacharyya and Vauquline, 2013; Sarma, 2009). In this case, MGNREGA is an important step for ensuring economic empowerment of rural women-the findings suggest that in the Ambari village, women have been developing their 'power within' to empower themselves through the scheme-power with (Rowlands, 1995; Bhattacharyya et al., 2011; Bhattacharyya and Vauquline, 2013). In the case of Assam, and more specifically in the study area, it is found that the objective of the scheme is not properly fulfilled. Therefore, proper monitoring and implementation of the scheme remains essential. People in the study village are very hardworking and enthusiastic to work at MGNREGA, have the job cards but are not employed for 100 days, which has been central objective of the scheme (Fraser, 2015; Ghosh,
2015). The mode of payment here in the village has been so irregular that led to slow progress of works and deterioration in the quality of the work completed. This research has however been conducted only in a small village in the district of Goalpara. I urge for similar research in other parts of Assam and elsewhere in the country; and learn from the findings of those researches and then plug the loopholes of the scheme for its proper implementation.

\section{References}

Agarwal, B. (2000). Gender and Command over Property: An Economic Analysis of South Asia, Kali for Women: New Delhi.

Bhattacharyya, R. (2009). Examining the Changing Status and Role of Middle Class Assamese Women: Lessons from the Lives of University Students, PhD thesis, Newcastle University, UK.

Bhattacharyya, R. (2013). Are We Empowered? Stories of Young Indian Working Women, Saarbrücken, Germany: Lap Lambert Academic Publishing, ISBN: 978-3-659-20580-4.

Bhattacharyya, R. and Vauquline, P. (2013). A Mirage or a Rural Life Line?: Analysing the Impact of Mahatma Gandhi Rural Employment Guarantee Act on Women Beneficiaries of Assam, Space and Culture, India, 1(1), 83-101.

Bhattacharyya, R., Vauquline, P. and Singh, S. (2011). Towards a Socially Sustainable India: An Analysis of National Rural Employment Guarantee Scheme, 2006. In S.K. Singh, Raj Kumar, H.P. Mathur, N.B. Singh and V.K. Kumra (eds.). Energy Resources, Alternative Search and Sustainable Development, New Delhi: Shree Publishers, 73-88, ISBN: 978-81-8329-395-2.

Dutta, P. and Murgai, R. and Ravallion, M. and Van de Walle, Dominique P. (2012, 1March). 
Does India's Employment Guarantee Scheme Guarantee Employment? World Bank Policy Research Working Paper No. 6003.

Eyben, R. Kabeer, N. and Cornwall, A. (2008). Conceptualising Empowerment and the Implications for Pro-poor Growth, Paper prepared for OECD-DAC POVNET Brighton: Institute of Development Studies.

FAO, (1995). Women, Agriculture and Rural Development: A Synthesis Report of the Near East Region. Sustainable Development Department (SD), Food and Agriculture Organization of the United Nations (FAO).

Fraser, N. (2015). Social Security through Guaranteed Employment, Social Policy \& Administration: An International Journal of Policy and Research, 49 (6), 679-694, DOI: 10.1111/spol.12164.

Gionetten V., Groverman, V., Walsum, E.V. and Zuidberg, L. (1994). Assessing the Gender Impact of Development Projects: Case Studies from Bolivia, Burkina Faso and India, Intermediate Technology Publications, United Kingdom, pp. 17-26.

Golla, A, Malhotra, A. Nanda, P. and Mehra, R. (2011). Understanding and Measuring Women's Economic Empowerment: Definition, Framework, Indicators, Washington DC: International Centre for Research on Women.

Ghosh Jayati (2015 5 February). India's Rural Employment Programme Is Dying a Death of Funding Cuts, The Guardian, available at: http://www.theguardian.com/global-

development/2015/feb/05/india-ruralemployment-funding-cuts-mgnrega.

Gupta, R., and Gupta, B.K. (1987). Role of Women in Economic Development, Yojana, 31(18), 28-32.

Liu, Y. and Barrett Christopher B. (2013). Heterogenous Pro-Poor Targeting in the National Rural Employment Guarantee Scheme, Economic and Political Weekly, XLVIII (10), 4653.

Krishnaraj, Maithreyi and Aruna Kanchi (2008). Women Farmers of India, National Book Trust.
Monitoring and Impact Assessment Of Mahatma Gandhi National Rural Employment Guarantee Scheme: A Study in Tripura- NIRD-NERC, Guwahati, Sponsored by Ministry of Statistics and Programme Implementation, Government of India

Mehta, S. and Sethi, N. (1997). Targeting Women for Developing, Social Welfare, 43(10), 14-16.

Morrison, A., Raju, D., Sinha, N, (2007): Gender Equality, Poverty and Economic Growth, The World Bank, Gender and Development Group, Policy Research Working Paper 4349.

Narayanan, S. and Das U. (2014). Women Participation and Rationing in the Employment Guarantee Scheme, Economic and Political Weekly, XLIX (46), 46-53.

Rowlands, J. (1995). Empowerment Examined, Development in Practice, 5(2), 101-107.

Sarma, R. B. (2009). Feminist Political Economy. In Kitchin R. and Thrift, N. (eds.) International Encyclopedia of Human Geography, Oxford: Elsevier, Volume 4, 79-86

Sen, G. and Sen, C. (1985). Women's Economic Work and Economic Activity, Economic and Political Weekly, Review of Women Studies, 20(17): 18-22.

Sudarshan, R.M. (2011).India's National Rural Employment Guarantee Act: Women's Participation and Impacts in Himachal Pradesh, Kerala and Rajasthan, CSP Research Report, 06, Institute of Development Studies and Centre for Social Protection, http://www.ids.ac.uk/files/dmfile/ResearchRep ort06FIN AL.pdf (accessed 01 March 2013).

Tornqvist, A. and Schmitz, C. (2009). Women's Economic Empowerment: Scope for Sida's Engagement, Working Paper December. Stockholm: SIDA.

Vepa, S Swarna (2005). Feminisation of Agriculture and Marginalisation of their Economic Stake, Economic and Political Weekly, 40(25), 2563-2568. 